УДК 616.133.283.3-005.6-007.24

\title{
Патологічна деформація та тромбоз лівої внутрішньої сонної артерії. Випадок із практики
}

\author{
I.I. Кобза ${ }^{1}$, Т.І. Кобза ${ }^{2}$, Ю.С. Мота ${ }^{1}$, I.В. Кирилич ${ }^{2}$ \\ ${ }^{1}$ Львівський наиіональний медичний університет імені Данила Галииького, кафедра хірургії №2; \\ ${ }^{2}$ Львівська обласна клінічна лікарня, Львів
}

\section{Реферат}

Ділянки патологічних вигинів сонних артерій небезпечні виникненням тромбоутворення 3 подальшим перекриттям кровоплину. У даному клінічному спостереженні у хворої віком 54 роки, 3 діагнозом пристінкового тромбозу сонних артерій патологічна звивистість внутрішньої сонної артерії перешкодила подальшому просуванню тромбоембола через кровоносне русло, що дозволило уникнути небезпечних ускладнень при своєчасному проведенні хірургічного втручання.

Ключові слова: патологічна звивистість, тромбоз, ішемічний інсульт, ретроградна каротидна тромбендартеректомія.

Pathological deformation and thrombosis of the left internal carotid artery. Case report

I.I. Kobza ${ }^{1}$, T.I Kobza ${ }^{2}$, Yu.S. Mota ${ }^{1}$, I.V. Kyrylych ${ }^{2}$

${ }^{1}$ Danylo Halytsky National Medical University in Lviv, Department of Surgery № 2;

${ }^{2}$ Lviv Regional Clinical Hospital, Lviv

\section{Abstract}

Areas of pathological bends of the carotid arteries are dangerous due to the formation of thrombus with subsequent overlap of blood flow. However, in this clinical observation, in 54 year old patient, with a diagnosis of carotid thrombosis, pathological tortuosity of the internal carotid artery prevented the further promotion of thromboembol through the bloodstream, which allowed to avoid dangerous complications at timely performed surgical intervention.

Key words: pathological tortuosity, thrombosis, ischemic stroke, retrograde carotid thrombendarterectomy.

Вступ. Однією 3 найчастіших причин виникнення ішемічного інсульту є оклюзійно-стенотичні ураження екстракраніальних відділів внутрішньої сонної артерії (ВСА) з переважною локалізацією у ділянці біфуркації загальної сонної артерії (ЗагСА), гирлі та початкових відділах ВСА. Патологічна деформація брахіцефальних судин (різка звивистість, перегини, петлі) є другою за частотою, після атеросклерозу, причиною виникнення симптомів хронічної ішемії мозку. Дана патологія спостерігається при поєднанні атеросклерозу та гіпертензії, з найчастішою локалізацією в ЗагСА і ВСА, перед входом останньої в череп.

Стійкі залишкові зміни після перенесеного інсульту спостерігаються у 30\%, працездатність відновлюється лише у 10\% хворих. 5-річне виживання пацієнтів 3 оклюзією ВСА становить 63$77 \%$, а ризик повторної ішемічної події впродовж 3 місяців після гострого інсульту може сягати 20$30 \%$, незважаючи на проведене консервативне лікування.

Тому хірургічне лікування при оклюзійностенотичних ураженнях і патологічних деформаціях сонних артерій $є$ одним із перспективних напрямів як первинної, так і вторинної профілактики ішемії головного мозку [1-4].

Мета дослідження. Покращення діагностики i результатів лікування патологічної деформації та тромбозу ВСА.

Матеріали та методи. Проаналізовано випадок діагностики та хірургічного лікування патоло- гічної деформації та тромбозу лівої ВСА у хворої віком 54 роки.

\section{Опис клінічного спостереження}

Хвора віком 54 роки 24.05.2017 р. госпіталізована у відділення хірургії судин Львівської обласної клінічної лікарні зі скаргами на погіршення рухів у правій руці, розлади мови. Із анамнезу: 3 27.04.2017 р. по 08.05.2017 р. перебувала на стаціонарному лікуванні у відділі судинної неврології ОКЛ м. Івано-Франківськ $з$ приводу гострого порушення мозкового кровообігу за ішемічним типом в басейні лівої середньомозкової артерії (19.04.2017p.) з правобічним верхнім монопарезом (плегія китиці, помірний парез верхньої кінцівки). Важкість по шкалі Ренкіна - 3 бали, по шкалі Бартела - 75 балів. 26.04.2017 р. - гострий трансмуральний інфаркт міокарда передньоперетинкової бокової гілки лівого шлуночка. Стентування проксимального відділу LAD DES (27.04.2017 р.), peцидивуючий перебіг (рецидив 28.04.2017 р. - тромбоз стенту). Стентування медіального відділу LAD (2 BMS). CH I Killip. Гіпертонічна хвороба III стадія, ступінь 2, ризик 4.

Загальний стан хворої середньої важкості. Шкірні покриви та видимі слизові блідо-рожеві. Пульс - 90 уд/хв., АТ - 110/80 мм рт. ст. Аускультативно над сонними артеріями ліворуч вислуховується систолічний шум.

Загальний аналіз крові: еритроцити $3,7 \times 10^{12}$ лл, гемоглобін - 114 г/л, КП - 0,9, тромбоцити $-259,0 \times 10^{9}$, лейкоцити $-4,0 \times 10^{9} /$ л, е $-5 \%$, 
$\Pi-2 \%$, с $-43 \%$, лімф. $-31 \%$, м - 18\%, ШЗЕ -32 мм/год. Біохімічний аналіз крові: білірубін - 12,0 мкмоль/л, глюкоза - 6,3 ммоль/л, креатинін - 0,058 ммоль/л, сечовина - 4,1 ммоль/л, $\mathrm{K}^{+}-3,5$ ммоль/л, $\mathrm{Na}^{+}-141$ ммоль/л. Коагулограма: ПЧ - 19,0", ПІ $84 \%$, фібриноген - 3,99 г/л, гематокрит - 0,43.

ЕКГ: синусова тахікардія, ЧСС - 91 уд/хв, нормальне положення електричної осі серця. Перенесений передньоперегородковий інфаркт міокарда лівого шлуночка.

СКТ ангіографія судин голови та шиї: в апікальних відділах тім'яної ділянки лівої півкулі головного мозку (ГМ) візуалізується гіподенсивна зона чітко сформованої ішемії, розмірами 53×40x40 мм (рис. 1, 2). Супраперивентрикулярно в тім'яних відділах обох півкуль ГМ - гіподенсивні вогнища енцефаломаляції, розмірами 6-9 мм. У потиличній ділянці правої півкулі ГМ - енцефаломаляційно-кистозна зона, розмірами 20х20 мм із наявністю по периферії зони повторної ішемії, розміром до 20 мм.

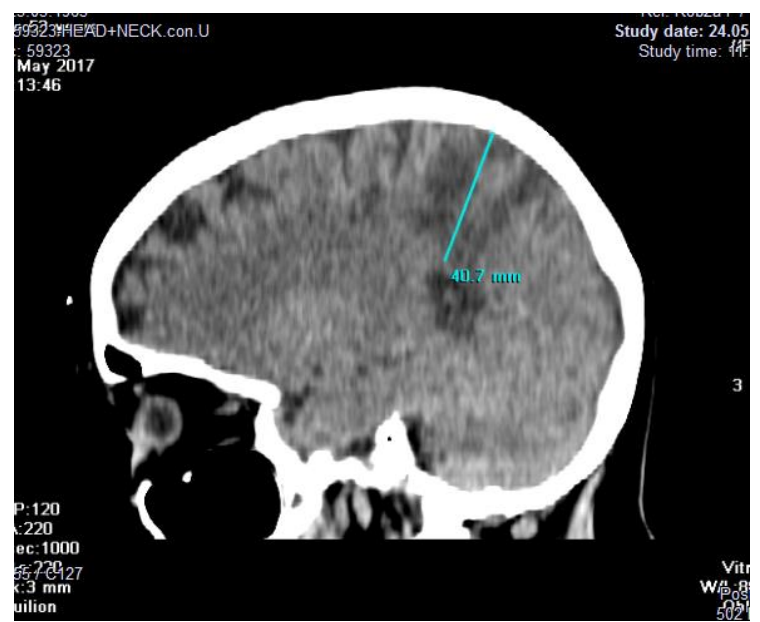

Рис. 1. Гіподенсивна зона ішемії у тім'яній частці лівої півкулі ГМ (сагітальна площина).

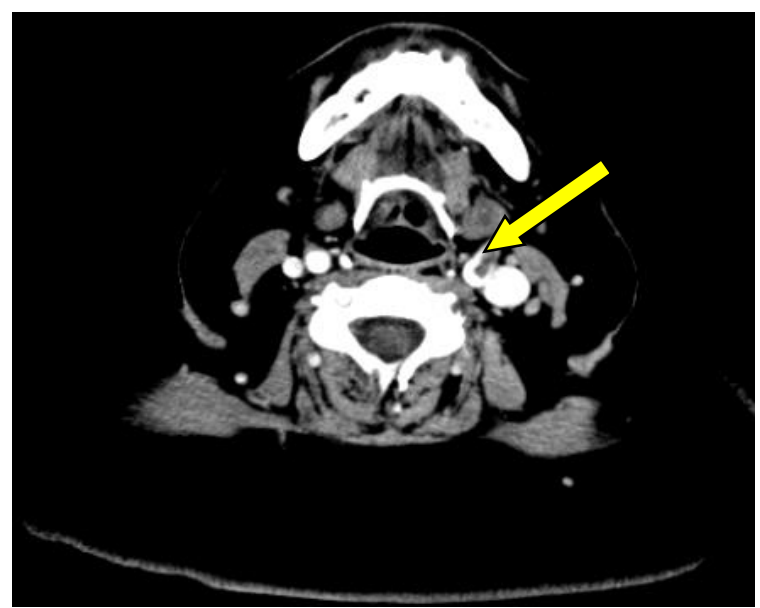

Рис. 3. Тромбоз лівої ВСА.

Ультразвукове обстеження гілок дуги аорти: петлеподібна девіація та намистоподібна форма обох ВСА 3 порушенням гемодинаміки як при стенозі 60 \% 3 обох сторін. Стінки - потовщені.
На рівні середньоверхньої третини лівої ЗагСА візуалізується тромботична маса, локалізована в центрі просвіту судини із перфузією контрастної речовини по периферії (пристінково). Тромботична маса поширюється до рівня середніх третин лівої ВСА (рис. 3, 4) та лівої зовнішньої сонної артерії (ЗовСА), в просвіті цих судин локалізована в центральній частині, а на рівні біфуркації лівої ЗагСА - дещо прикріплена до стінки судини. Просвіт судин на рівні тромба субтотально стенозований, без оклюзії. Петлиста звивистість лівої та S-подібна середньої третини правої ВСА. Висновок: тромбоз просвіту лівих ЗагСА, ЗовСА та ВСА (екстракраніальний сегмент) із субтотальним стенозуванням просвіту судини. Звивистість обох ВСА. Ішемія в басейні лівої та правої середніх мозкових артерій. Постінсультні енцефаломаляційні зміни в обох півкулях ГМ. Гіпоплазія А1 сегменту лівої передньої мозкової артерії.

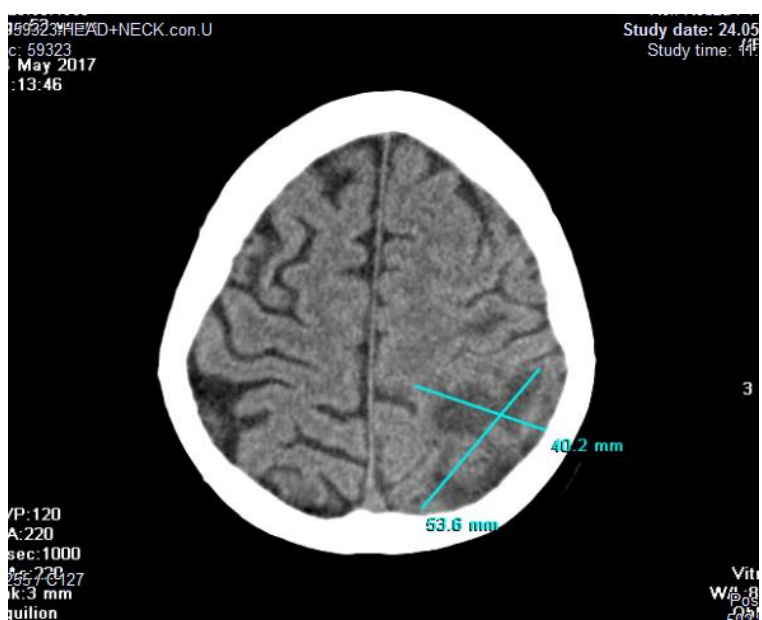

Рис. 2. Гіподенсивна зона ішемії у тім'яній частці лівої півкулі ГМ (фронтальна площина).

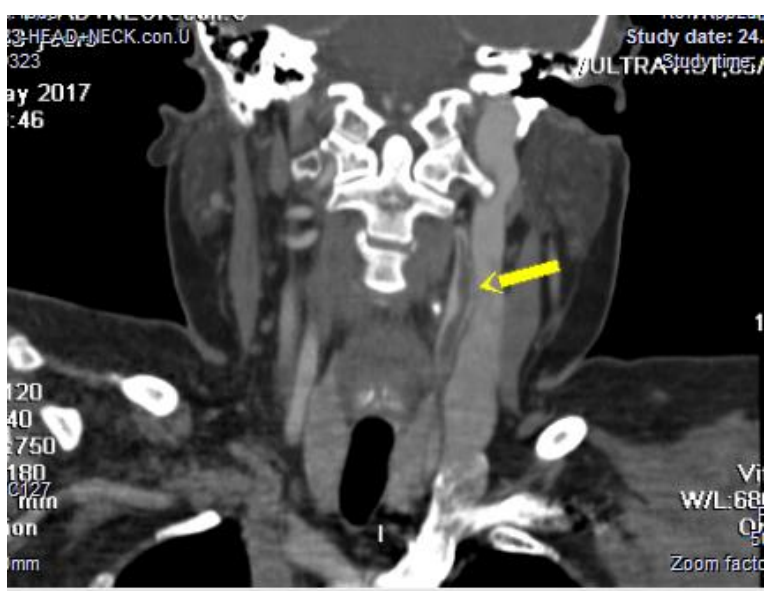

Рис. 4. Тромбоз лівої ВСА.

Комплекс інтима-медіа товщиною 0,8-1,0 мм. Стеноз $70 \%$ біфуркації лівої ЗагСА та початку ВСА через пристінковий тромбоз (тромбоембол?), що поширюється на 50-60\% у просвіт проксима- 
льних 1/3 внутрішньої та 1/2 ЗовСА. Ліва ВСА прохідна до входу в череп, кровотік магістрально порушений з ознаками підвищеного периферичного кровообігу. При доплерографії екстракраніальних ділянок вертебральних артерій виражена екстравазальна компресія лівої та правої вертебральних артерій.

25.05 .2017 p. $13^{20}-15^{10}$. Операція: ретроградна каротидна тромбендартеректомія з сонних артерій з редресацією лівої внутрішньої сонної артерії.

Під місцевим знечуленням по передньовнутрішньому краю лівого кивального м'язу з рет-

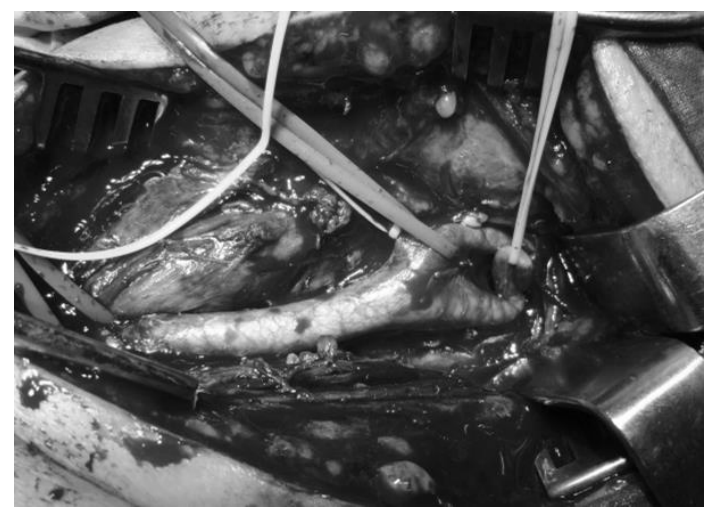

Рис. 5. Виділені ЗагСА, ВСА і ЗовСА. роюгулярного доступу виділено загальну, зовнішню і внутрішню сонні артерії (рис. 5). Тромбоембол у ділянці біфуркації 3 переходом на гирло внутрішньої сонної артерії, протяжністю до 3 см (рис. 6). Дистальніше ВСА гіпоплазована, діаметром до 2 мм. Проба перетискання ВСА неврологічного дефіциту не викликала. ВСА пересічено. Проведено ретроградну каротидну тромбендартеректомію (рис. 7). ВСА редресовано до ЗагСА. Відновлено кровоплин, щільний гемостаз, дренування рани. Рана пошарово зашита. Асептична пов'язка.

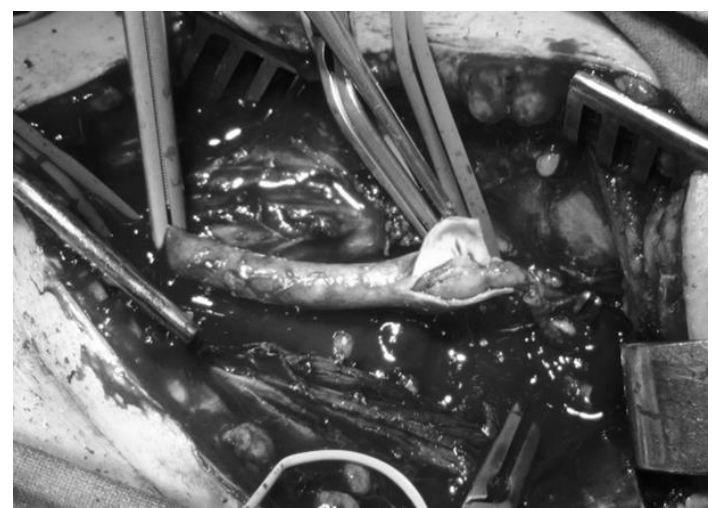

Рис. 6. Тромбоембол в ділянці біфуркації з переходом на гирло ВСА.

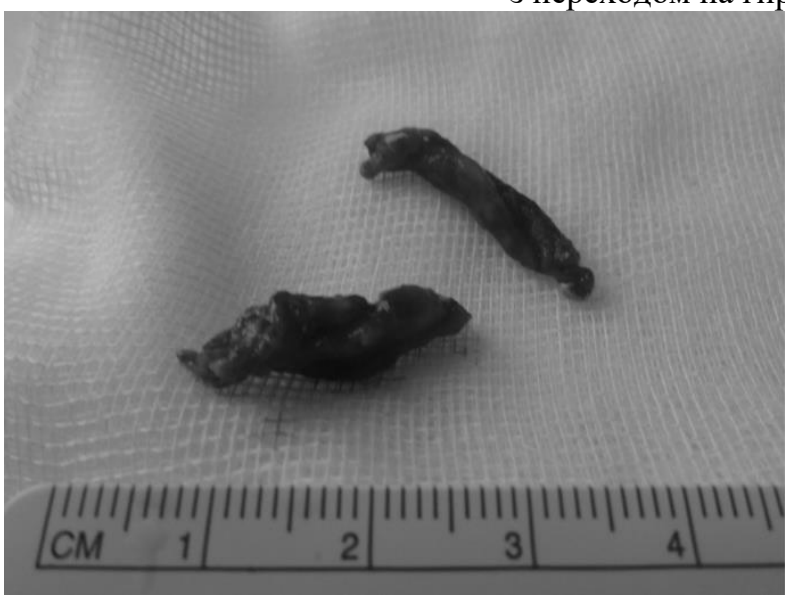

Рис. 7. Видалені тромбоемболи.

У післяопераційному періоді хвора отримувала цибор-3500, аспірин-кардіо, брилінта, діуремід, конкор, каліпоз, цефтріаксон $\rightarrow$ левофлоксацин, метронідазол, флуконазол, лінекс, ентерол, тирозол, адаптол. Перебіг післяопераційного періоду без ускладнень, 3 поступовим регресом неврологічного дефіциту, рана загоїлась первинним натягом, шви знято на 10 добу.

При контрольному УЗД гілок дуги аорти через 3 місяці: ліва ВСА прохідна, просвіт вільний. ПСШ - до 108 см/с. У ділянці біфуркації ЗагСА локальне потовщення медіа-інтимального комплексу до 1,3 мм.

Результати досліджень та їх обговорення. У даному клінічному спостереженні, у 54-річної хворої, на підставі результатів інструментальних методів досліджень (ультразвукове обстеження гілок дуги аорти, СКТ ангіографія судин голови та шиї) були підтверджені: пристінковий тромбоз лівої ЗагСА, ЗовСА та ВСА (екстракраніальний сегмент) із субтотальним стенозуванням просвіту судини, патологічна звивистість обох ВСА, що стало безпосереднім показанням до операційного втручання.

Ділянки патологічних вигинів сонних артерій небезпечні виникненням тромбоутворення 3 подальшим перекриттям кровоплину [3]. У даному клінічному спостереженні патологічна звивистість BCA перешкодила подальшому просуванню тромбоембола через кровоносне русло, що дозволило уникнути небезпечних ускладнень при своєчасному проведенні хірургічного втручання. 
Таким чином, своєчасна діагностика та адекватне хірургічне втручання - ретроградна каротидна тромбендартеректомія з редресацією лівої внутрішньої сонної артерії дозволили попередити виникнення нових епізодів дистальної емболізації.
Висновки. Ретроградна каротидна тромбендартеректомія у хворих із тромбозом сонних артерій дозволяє запобігти виникненню повторних ішемічних інсультів і значно покращити реабілітаційні заходи в пацієнтів після перенесеного гострого порушення мозкового кровообігу.

Інформація про конфлікт інтересів. Автори заявляють про відсутність конфлікту інтересів при виконанні наукового дослідження та підготовці даної статті.

Інформація про фінансування. Автори гарантують, що вони не отримували жодних винагород у будь-якій формі, здатних вплинути на результати роботи.

Особистий внесок кожного автора у виконання роботи:

Кобза I.I. - розробка концепції і дизайну дослідження, аналіз отриманих даних, редагування, статистична обробка даних;

Кобза Т.І. - збір матеріалу дослідження, розробка дизайну дослідження, аналіз отриманих даних;

Мота Ю.С. - збір матеріалу дослідження, аналіз отриманих даних, підготовка тексту статті;

Кирилич I.В. - збір матеріалу дослідження, аналіз отриманих даних.

\section{Список використаної літератури}

1. Гавриленко А.В. ${ }^{1,2}$, Куклин А.В. ${ }^{1}$, Хрипков А.С. Оценка эффективности реконструктивных операций на сонных артериях в сочетании стеноза и патологической извитости. Ангиология и сосудистая хирургия. 2014; Т. 20; № 3; 116-122.

2. Казаков Ю.И, Иванова О.В., Поспелова А.М. и соавт. Особенности діагностики, хирургическая тактика, оценка эффективности реконструктивних операцій при патологической извитости внутренных сонних артерій. Ангиология и сосудистая хирургия. 2015; Т. 21; № 4; 153-156.

3. Кобза I.I. Патологія сонних артерій: посібник-атлас. Львів; 2008; 106.

4. Zenteno M., Viñuela F., Moscote-Salazar L.R. et. al. Clinical implications of internal carotid artery tortuosity, kinking and coiling: a systematic review. Romanian Neurosurgery. 2014; XXI 1: 50-59.

Стаття надійшла до редакції: 7.02.2020 p. 